\title{
Organisasi Salah Satu Faktor Pendukung Prestasi Belajar Mahasiswa
}

\author{
Kadek Rai Suwena ${ }^{1 *}$, Made Ary Meitriana ${ }^{2}$ \\ 1,2 Jurusan Pendidikan Ekonomi, Universitas Pendidikan Ganesha Singaraja- Indonesia
}

\section{A R T I C L E I N F O \\ Article history: \\ Received 30 September 2018 \\ Received in revised form 5 October 2018 \\ Accepted 29 November 2018 \\ Available online 12 \\ December 2018 \\ Kata Kunci: \\ prestasi belajar, mahasiswa aktif dan tidak aktif dalam \\ organisasi kemahasiswaan \\ Keywords: \\ achievement, active and inactive students in student organizations}

\begin{abstract}
A B S T R A K
Penelitian ini bertujuan untuk (1) mengetahui prestasi belajar mahasiswa yang aktif dalam organisasi kemahasiswaan, (2) mengetahui prestasi belajar mahasiswa yang tidak aktif dalam organisasi kemahasiswaan, dan (3) mengetahui perbedaan prestasi belajar antara mahasiswa yang aktif dan tidak aktif dalam organisasi kemahasiswaan. Penelitian ini menggunakan pendekatan kuantitatiif dengan metode komparatif. Subjek dalam penelitian ini adalah mahasiswa yang aktif dan tidak aktif dalam organisasi kemahasiswaan Fakultas Ekonomi Undiksha, sedangkan objek penelitian adalah prestasi belajar mahasiswa yang aktif dan tidak aktif dalam organisasi kemahasiswaan. Data dikumpulkan dengan metode dokumentasi dan wawancara. Metode analisis yang digunakan adalah analisis Independent-Sample T-Test yang diolah dengan program SPSS 17.0 for windows. Hasil penelitian menunjukan bahwa (1) rata-rata nilai prestasi belajar mahasiswa yang aktif dalam organisasi kemahasiswaan sebesar 3,36. tergolong dalam kategori sangat baik (2) rata-rata nilai prestasi belajar mahasiswa yang tidak aktif dalam organisasi kemahasiswaan sebesar 2,80 tergolong dalam kategori baik (3) terdapat perbedaan yang signifikan prestasi belajar mahasiswa yang aktif dan tidak aktif dalam organisasi kemahasiswaan di Fakultas Ekonomi Undiksha, dengan perolehan $t_{\text {hitung }}>t_{\text {tabel }}(8,974>1,969)$.
\end{abstract}

\section{A B S T R A C T}

The research was aimed to (1) determine the achievement of students who are active in student organizations, (2) determine the achievement of students who are not active in student organizations. (3) determine differences in academic achievement between students who are active and inactive in student organizations. This study used the quantitative approach with comparative method. Subjects of this study were active and non active students in student organisation in the Faculty of Economics of Undiksha, while the object of the study were the achievement of students who are active and inactive in student organizations. The data were collected using documentation and interview method. The analytical method used int his study was analysis of Independent-Sample T-Test that was processed using SPSS 17.0 for windows. The results showed that (1) the average value of the achievement of students who are active in student organizations was 3.36 wich was classified into excellent category, (2) the average value of the achievement of students who are inactive in student organizations was 2,80 which was classified into either category, (3) there is a significant difference in the achievement of students who are active and inactive in student organizations at the Faculty of Economics Undiksha, with the acquisition of $\mathrm{t}_{\mathrm{value}}>\mathrm{tt}_{\mathrm{able}}$ $(8.974>1.969)$.

\footnotetext{
* Corresponding author.

E-mail addresses: kadek_Suwena@yahoo.co.id (Kadek Rai Suwena)
} 


\section{Pendahuluan}

Mahasiswa merupakan peserta didik yang menjalani pendidikan tinggi di sebuah universitas atau perguruan tinggi. Mahasiswa diharapkan tidak hanya menekuni ilmu dalam bidang akademik, tetapi juga aktif dalam bidang non akademik untuk mengembangkan Soft skills-nya agar menjadi lulusan yang mandiri, penuh inisiatif, bekerja secara cermat, penuh tanggung jawab dan gigih. Implementasi dalam bidang akademik diperoleh dari proses belajar mengajar dalam perkuliahan, sedangkan bidang non akademik diperoleh melalui kegiatan organisasi kemahasiswaan yang bisa menampung hasrat mahasiswa dan sebagai media mengasah dalam mempertajam bakat dan minatnya sebagai keterampilan pendukung dalam kesuksesan hidup. Dalam aktivitas keseharianya di kampus mahasiswa dihadapkan pada dua pilihan yaitu mahasiswa yang hanya menggunakan waktunya untuk perkuliahan dan mahasiswa yang selain mengikuti perkuliahan juga menggunakan waktunya untuk pemenuhan bakat dan minat melalui organisasi kemahasiswaan.

Berdasarkan UU No.12 Tahun 2012 Pasal 77 Tentang Pendidikan Tinggi, organisasi kemahasiswaan merupakan organisasi intra perguruan tinggi yang memiliki fungsi (a) mewadahi kegiatan mahasiswa dalam mengembangkan bakat, minat, dan potensi mahasiswa, (b) mengembangkan kreativitas, kepekaan, daya kritis, keberanian, kepemimpinan, serta rasa kebangsaan, (c) memenuhi kepentingan dan kesejahteraan mahasiswa, dan (d) mengembangkan tanggung jawab sosial melalui kegiatan pengabdian kepada masyarakat. Aktivitas mahasiswa tersebut harus berjalan secara sinergis dan terintegrasi dalam satu kesatuan yang harmonis sehingga pengembangan soft skill mahasiswa di perguruan tinggi dapat dicapai dengan sempurna.

Organisasi kemahasiswaan di perguruan tinggi menimbulkan adanya perbedaan aktivitas mahasiswa berdasarkan kegiatan sehari-hari yang mereka lakukan, yaitu mahasiswa yang aktif dan tidak aktif dalam organisasi kemahasiswaan. Mahasiswa yang aktif dalam kegiatan organisasi kemahasiswaan merupakan mahasiswa yang tidak hanya mengikuti kegiatan perkuliahan tetapi juga meluangkan waktunya untuk mengikuti kegiatan organisasi kemahasiswaan, sehingga memerlukan pembagian waktu yang tepat agar keduanya bisa berjalan secara sinergis. Sedangkan mahasiswa yang tidak aktif dalam organisasi kemahasiswaan merupakan mahasiswa yang hanya mengikuti kegiatan perkuliahan dan tidak aktif untuk kegiatan organisasi kemahasiswaan dan hanya berorientasi pada bidang akademik.

Dari penjelasan di atas jelas terlihat bahwa terdapat perbedaan jenis kegiatan yang dilakukan mahasiswa yang aktif dan mahasiswa yang tidak aktif dalam organisai kemahasiswaan. Namun keduanya juga memiliki kesamaan sebagai mahasiswa yang dituntut untuk belajar dengan demikian dapat menyelesaikan studi tepat waktu dengan nilai indeks prestasi yang bagus. Belajar merupakan suatu proses perubahan tingkah laku sebagai hasil interaksi individu dengan lingkungannya dalam memenuhi kebutuhan hidupnya. Menurut Sugihartono (2007: 74) belajar merupakan suatu proses memperoleh pengetahuan dan pengalaman dalam wujud perubahan tingkah laku dan kemampuan bereaksi yang relatif permanen atau menetap karena adanya interaksi individu dengan lingkungannya. Sejalan dengan yang dikatakan Slameto (2010: 2) bahwa "belajar ialah suatu proses usaha yang dilakukan seseorang untuk memperoleh suatu perubahan tingkah laku yang baru secara keseluruhan, sebagai hasil pengalamannya sendiri dalam interaksi dengan lingkungannya.

Menurut Muhibbin Syah (2010: 141) "prestasi adalah tingkat keberhasilan siswa dalam mencapai tujuan yang ditetapkan dalam sebuah program”. Sedangkan menurut Sumadi Suryabrata (2006: 297), prestasi adalah "nilai yang merupakan perumusan terakhir yang dapat diberikan oleh guru mengenai kemajuan/prestasi belajar siswa selama masa tertentu". Setiap kegiatan belajar yang dilakukan mahasiswa akan menghasilkan perubahan-perubahan pada dirinya. Seperti yang dinyatakan oleh Sutratinah (2001: 43) bahwa "prestasi belajar adalah penilaian hasil usaha kegiatan yang dinyatakan dalam bentuk simbul, angka, huruf maupun kalimat yang dapat mencerminkan hasil yang sudah dicapai oleh setiap anak dalam periode tertentu. Berdasarkan beberapa pengertian prestasi belajar dapat disimpulkan bahwa prestasi belajar mahasiswa adalah hasil penilaian dari kegiatan belajar yang telah dilakukan dan merupakan bentuk perumusan akhir yang diberikan oleh dosen untuk melihat sampai di mana kemampuan mahasiswa yang dinyatakan dalam bentuk simbul, angka, huruf maupun kalimat yang dapat mencerminkan hasil yang sudah dicapai. Penilaian adalah kegiatan yang dilakukan oleh pelatih yaitu pendidik (guru dan dosen) untuk mengukur dan mengetahui tingkat keberhasilan proses dan hasil belajar mengajar dalam perkuliahan. Penilaian proses adalah penilaian yang dilakukan pada saat kegiatan belajar mengajar berlangsung, sedangkan penilaian akhir dari proses belajar mengajar tertera pada Kartu Hasil Studi (KHS).

Dalam kegiatan pembelajaran, mahasiswa dikatakan berhasil atau tidak, salah satu caranya dengan melihat nilai-nilai hasil perolehan mahasiswa dalam Kartu Hasil Studi (KHS) yang mencerminkan prestasi belajar atau sejauh mana tingkat keberhasilan siswa mengikuti kegiatan belajar. Menurut Sugihartono 
(2007: 130) dalam kegiatan belajar mengajar, pengukuran hasil belajar dimaksudkan untuk mengetahui seberapa jauh perubahan tingkah laku siswa setelah menghayati proses belajar, maka pengukuran yang dilakukan guru lazimnya menggunakan tes sebagai alat ukur. Hasil pengukuran tersebut berwujud angka ataupun pernyataan yang mencerminkan tingkat penguasaan materi pelajaran bagi para siswa, yang lebih dikenal dengan prestasi belajar.

Perguruan tinggi tidak pernah lepas dari aktvitas mahasiswa. Banyak aktivitas yang diselenggarakan mahasiswa sebagai bentuk kreativitas dan pengembangan soft skill. Untuk itu perguruan tinggi menyediakan wadah atau wahana pengembangan kreativitas dan soft skill dalam bentuk organisasi kemahasiswaan. Organisasi kemahasiswaan adalah suatu wadah yang menampung mahasiswa dalam rangka membina dan mengembangkan bakat dan minat. Organisasi kemahasiswaan Universitas Pendidikan Ganesha merupakan wahana pengembangan diri mahasiswa ke arah peningkatan kemampuan kognitif, afektif, dan psikomotorik secara seimbang. Pengembangan diri mahasiswa diwadahi dalam kegiatan esktrakulikuler yang meliputi bidang organisasi dan kepemimpinan, penalaran dan keilmuan, minat dan bakat, kesejahteraan mahasiswa dan kepekaan sosial (bakti sosial). Organisasi kemahasiswaan Univesitas Pendidikan Ganesha adalah organisasi kemahasiswaan intra-perguruan tinggi yang berkedudukan di dalam kampus. berikut.

Kegiatan organisasi kemahasiswaan dapat dikelompokkan menjadi lima bidang, antara lain sebagai

(1) Bidang Organisasi dan Kepemimpinan

Program dan kegiatan organisasi dan kepemimpinan dimaksudkan untuk menata organisasi kemahasiswaan sehingga menjadi organisasi yang efisien, efektif, dan demokratis. Di samping itu, pengembangan program bidang ini ditujukan untuk membelajaran mahasiswa sehingga menjadi insan yang memiliki kemampuan memimpin dan dipimpin secara cerdas dan profesional.

(2) Bidang Penalaran dan Keilmuan

Program kegiatan penalaran dan keilmuan dimaksudkan untuk mengembangkan daya pikir (nalar) dan wawasan keilmuan mahasiswa sebagai insan akademis dan calon ilmuwan. Melalui pengembangan program penalaran dan keilmuan, diharapkan mahasiswa memiliki kemampuan untuk mengenal, menganalisis, dan memecahkan persoalan-persoalan yang dihadapi secara objektif, rasional, dan kritis berdasarkan kaidah penalaran dan keilmuan.

(3) Bidang Minat dan Bakat

Program pengembangan minat dan bakat mahasiswa amat banyak bentuk dan jenisnya, namun yang umum terdapat di perguruan tinggi dan dikembangkan di Universitas Pendidikan Ganesha meliputi bidang olah raga, kesenian, kepramukaan, kepencintaalaman, Korps Sukarela Palang Merah Indonesia (KSR-PMI), resimen mahasiswa, dan pers mahasiswa.

(4) Bidang Kesejahteraan Mahasiswa

Pengembangan kegiatan kesejahteraan mahasiswa bertujuan untuk memenuhi kebutuhan mahasiswa, baik yang bersifat material maupun spiritual, dengan harapan dapat menunjang proses pengembangan diri mahasiswa dan kelancaran studinya sebagai insan akademik.

(5) Bidang Kepekaan/ Bakti Sosial

Bidang ini merupakan manifestasi kepekaan dan kepedulian mahasiswa terhadap lingkungan sosialnya.

Menurut Haris Zuhad (2008) mahasiswa aktif dalam organisasi adalah mahasiwa yang berada di perguruan tinggi yang berkerja aktif dalam mendorong atau menjadi inisiator pelaksanaan suatu atau berbagai kegiatan organisasi kemahasiswaan yang digeluti dilingkungan kampus. Adapun indikator mahasiswa yang dikatakan aktif dalam organisasi yaitu: (1) mempunyai jabatan sstruktural di organisasi yang di amanahkan kepadanya, (2) mempunyai pengaruh dan kemampuan leadership dan menjadi penggerak dalam organisasi kemahasiswaan. (3) kreatif dan kritis terhadap persoalan, (4) menonjol dalam kelompok mahasiswa karena memiliki jiwa kepemimpinan, sedangkan mahasiswa yang tidak aktif dalam organisasi kemahasiswaan adalah mahasiswa yang hanya berorientasi kepada kegiatan perkuliahan dan memiliki waktu lebih banyak dalam kegiatan akademik karena tidak menggunakan waktunya dalam kegiatan organisasi kemahasiwaan.

\section{Metode}

Penelitian ini menggunakan pendekatan kuantitatif dengan metode komparatif. Menurut Sugiyono (2010) metode komparatif bertujuan untuk membandingkan keberadaan suatu variabel atau lebih pada dua atau lebih sampel yang berbeda, atau pada waktu yang berbeda. Penelitan komparatif ini bersifat expost facto yaitu data yang dikumpulkan setelah peristiwa yang dipermasalahkan terjadi. Metode 
komparatif digunakan untuk mengetahui perbedaan prestasi belajar mahasiswa yang aktif dan tidak aktif dalam organisasi kemahasiswaan Fakultas Ekonomi Undiksha. Subjek dalam penelitian ini adalah mahasiswa yang aktif dan tidak aktif dalam organisasi kemahasiswaan Fakultas Ekonomi Undiksha Singaraja, sedangkan objek dalam penelitian ini adalah prestasi belajar mahasiswa yang aktif dalam organisasi dan mahasiswa yang tidak aktif dalam organisasi. Analisis yang digunakan dalam penelitian ini adalah Analisis deskriptif untuk mendeskripsikan peran organisasi dalam mendukung prestasi belajar mahasiswa. Menentukan kategori rata-rata prestasi belajar mahasiswa aktif dan tidak aktif dalam organisasi kemahasiswaan menggunakan rentang skala (1-4). Adapun perhitungan nilai skala sebagai berikut.

$$
\begin{aligned}
\text { Skala IPK } & =\text { nilai tertinggi IPK }- \text { nilai terendah IPK } \\
& =4,00-1,00 \quad \text { Kelas skala } \\
& =0,75
\end{aligned}
$$

Tabel 3.6 Kategori rentang IPK mahasiswa

\begin{tabular}{cc}
\hline Rentang Nilai IPK & Kategori \\
\hline $4,00-3,25$ & Sangat Baik \\
$3,25-2,50$ & Baik \\
$2,50-1,75$ & Cukup Baik \\
$1,75-1,00$ & Kurang Baik \\
\hline
\end{tabular}

Sumber : Perhitungan skala interval nilai IPK mahasiswa

\section{Hasil dan Pembahasan}

Berdasarkan dokumentasi yang didapat dari Bidang Akademik dan Kemahasiswaan Tata Usaha Fakultas Ekonomi

Tabel 4.1 Group Statistics Mahasiswa Aktif Dalam Organisasi Kemahasiswaan

Group Statistics

\begin{tabular}{lllrrr}
\hline & IPK & N & Mean & Std. Deviation & Std. Error Mean \\
\hline Mahasiswa & $\begin{array}{l}\text { Aktif dalam organisasi } \\
\text { kemahasiswaan }\end{array}$ & 129 & 3.3574 & .33945 & .02989 \\
\hline
\end{tabular}

Dari Tabel 4.1 terlihat bahwa rata-rata prestasi belajar mahasiswa yang aktif dalam organisasi kemahasiswaan sebesar 3,3574 dibulatkan 3,36. Hasil tersebut menunjukkan bahwa prestasi belajar mahasiswa yang aktif dalam organisasi kemahasiswaan Fakultas Ekonomi Undiksha tergolong dalam kategori sangat baik.

Prestasi Belajar Mahasiswa Yang Tidak Aktif Dalam Organisasi Kemahasiswaan

Berdasarkan dokumentasi yang didapat dari Bidang Akademik dan Kemahasiswaan Tata Usaha Fakultas Ekonomi Undiksha, diperoleh data prestasi belajar mahasiswa.

Tabel 4.2 Group Statistics Mahasiswa Tidak Aktif Dalam Organisasi Kemahasiswaan

\section{Group Statistics}

\begin{tabular}{llccrr}
\hline & IPK & N & Mean & $\begin{array}{c}\text { Std. } \\
\text { Deviation }\end{array}$ & Std. Error Mean \\
\hline Mahasiswa & $\begin{array}{l}\text { Tidak Aktif dalam organisasi } \\
\text { kemahasiswaan }\end{array}$ & 129 & 2.8017 & .34357 & .03025 \\
\hline
\end{tabular}


Dari tabel 4.2 jelas terlihat bahwa nilai rata mahasiswa yang tidak aktif dalam organisasi kemahasiswaan adalah 2,801

dibulatkan 2,80. Hasil tersebut menunjukkan bahwa prestasi belajar mahasiswa yang tidak aktif dalam organisasi kemahasiswaan Fakultas Ekonomi Undiksha tergolong dalam kategori baik.

Perbedaan Prestasi Belajar Mahasiswa Yang Aktif dan Tidak Aktif Dalam Organisasi Kemahasiswaan.

Berdasarkan rata-rata pretasi belajar mahasiswa yang aktif dalam organsasi kemahasiswaan diperoleh mean 3,3574 dibulatkan 3,36 dan prestasi belajar mahasiswa yang tidak aktif dalam organisasi kemahasiswaan diperoleh mean 2,801 dibulatkan 2,80. Dengan demikian, dari nilai rata-rata yang diperoleh tersebut dapat ditarik kesimpulan bahwa ada perbedaan prestasi belajar mahasiswa yang aktif dan tidak aktif dalam organisasi kemahasiswaan Fakultas Ekonomi Universitas Pendidikan Ganesha. Untuk mengetahui signifikan perbedaan digunakan analisis untuk menguji hipotesis yang diajukan dalam penelitian ini, sehingga hipotesis tersebut dapat diterima kebenarannya atau ditolak kebenarannya. Berdasarkan analisis uji Independent-Sample T-Test dengan bantuan program SPSS 17.00 for windows diperoleh data sebagai berikut.

Tabel 4.3 Uji Independent-Sample T test

Independent Samples Test

\begin{tabular}{llrr}
\hline & & \multicolumn{2}{c}{$\begin{array}{c}\text { Mahasiswa } \\
\text { Equal variances } \\
\text { assumed }\end{array}$} \\
\hline $\begin{array}{l}\text { Levene's Test for } \\
\text { Equality of Variances }\end{array}$ & F & .004 & assumed \\
t-test for Equality of & Sig. & .951 & 8.974 \\
Means & T & 8.974 & 255.963 \\
& Df & 256 & .000 \\
& Sig. (2- & .000 & .38163 \\
& tailed) & .38163 & .04252 \\
& Mean & .04252 & .29789 \\
& Difference & .29789 & .46537 \\
\hline
\end{tabular}

Berdasarkan tabel 4.3 dapat diketahui hasil (1) uji F test (Levene,s Test) yang merupakan prasyarat uji yang harus dilakukan sebelum dilakukanya uji Independent T test. Uji F diperoleh nilai probalitas 0,951, sedangkan dari hipotesis menyebutkan bila apabila nilai probabilitas lebih dari 0,05 maka Ho diterima. Dapat disimpukan bahwa nilai probabilitas 0,951 > 0,05 ini berarti kedua varian mahasiswa aktif dan mahasiswa tidak aktif dalam organisasi kemahasiswaan sama, dengan ini penggunaan uji t menggunakan equal variance assumed (diasumsikan kedua varian sama). (2) uji t diperoleh $t_{\text {hitung }}$ (equal variance assumed) adalah 8,974 sedangkan ttabel dengan taraf signifikan 5\% diperoleh 1,969. Ini berarti bahwa $t_{\text {hitung }}>t_{\text {tabel }}(8,974>1,969)$ maka Ha diterima, dari perbadingan tersebut ditarik kesimpulan bahwa ada perbedaan yang signifikan antara prestasi belajar mahasiswa yang aktif dan tidak aktif dalam organisasi kemahasiswaan Fakultas Ekonomi Undiksha.

Dari hasil penelitian yang dilakukan menunjukan bahwa ada perbedaan yang signifikan antara mahasiswa yang aktif dan tidak aktif dalam organisasi kemahasiswaan Fakultas Ekonomi Undiksha Singaraja ini ditunjukan dengan nilai $t_{\text {hitung }}(8,974)>t_{\text {tabel }}(1,969)$. Organisasi kemahasiswaan harus dimanfaatkan dengan baik dalam mengembangkan bakat maupun minat sesuai dengan tujuan organisasi kemahasiswaan Undiksha yaitu untuk mengembangkan diri mahasiswa ke arah perluasan wawasan untuk meningkatkan kecendikiaan serta integritas kepribadian dan membina, mengembangkan, serta menyalurkan potensi mahasiswa pada bidang-bidang kegiatan ekstrakulikuler dan kegiatan organisasi harus berjalan secara sinergis dengan kegiatan perkuliahan mahasiswa. 
Prestasi belajar mahasiswa adalah hasil penilaian dari kegiatan belajar yang telah dilakukan dan merupakan bentuk perumusan akhir yang diberikan oleh dosen untuk melihat sampai dimana kemampuan mahasiswa yang dinyatakan dalam bentuk simbol, angka, huruf maupun kalimat yang dapat mencerminkan hasil yang sudah dicapai. Penilaian adalah kegiatan yang dilakukan oleh pelatih yaitu pendidik (dosen) untuk mengukur dan mengetahui tingkat keberhasilan proses dan hasil belajar mengajar dalam perkuliahan. Penilaian proses adalah penilaian yang dilakukan pada saat kegiatan belajar mengajar berlangsung, sedangkan penilaian akhir dari proses belajar mengajar tertera pada Kartu Hasil Studi (KHS).

Dalam kegiatan pembelajaran, mahasiswa dikatakan berhasil atau tidak, salah satu caranya dengan melihat nilai-nilai hasil perolehan mahasiswa dalam Kartu Hasil Studi (KHS) yang mencerminkan prestasi belajar atau sejauh mana tingkat keberhasilan siswa mengikuti kegiatan belajar. Menurut Sugihartono (2007: 130) dalam kegiatan belajar mengajar, pengukuran hasil belajar dimaksudkan untuk mengetahui seberapa jauh perubahan tingkah laku mahasiswa setelah menghayati proses belajar, maka pengukuran yang dilakukan guru lazimnya menggunakan tes sebagai alat ukur. Hasil pengukuran tersebut berwujud angka ataupun pernyataan yang mencerminkan tingkat penguasaan materi pelajaran bagi para siswa, yang lebih dikenal dengan prestasi belajar.

Perguruan tinggi tidak pernah lepas dari aktvitas mahasiswa. Banyak aktivitas yang diselenggarakan mahasiswa sebagai bentuk kreativitas dan pengembangan soft skill. Untuk itu perguruan tinggi menyediakan wadah atau wahana pengembangan kreativitas dan soft skill dalam bentuk organisasi kemahasiswaan. Organisasi adalah setiap bentuk persekutuan antara dua orang atau lebih yang bekerja bersama serta secara formal terikat dalam rangka pencapaian suatu tujuan yang telah ditentukan dalam ikatan yang terdapat seorang atau beberapa orang yang disebut atasan dan seorang atau sekelompok orang yang disebut bawahan.

Organisasi kemahasiswaan adalah wadah pengembangan diri mahasiswa ke arah perluasan wawasan dan peningkatan kecendikiaan dan integritas kepribadian serta keterampilan mahasiswa, yang berkedudukan di perguruan tinggi. Organisasi kemahasiswaan adalah suatu wadah yang menampung mahasiswa dalam rangka membina dan mengembangkan bakat dan minat. Organisasi kemahasiswaan merupakan wahana pengembangan diri mahasiswa ke arah peningkatan kemampuan kognitif, afektif, dan psikomotorik secara seimbang. Pengembangan diri mahasiswa diwadahi dalam kegiatan esktrakulikuler yang meliputi bidang organisasi dan kepemimpinan, penalaran dan keilmuan, minat dan bakat, kesejahteraan mahasiswa dan kepekaan sosial (bakti sosial).

Jadi dapat disimpulkan bahwa prestasi belajar mahasiswa yang aktif dalam organisasi kemahasiswaan lebih baik dari prestasi belajar mahasiswa yang tidak aktif dalam organisasi kemahasiswaan.

\section{Simpulan dan saran}

Berdasarkan hasil penelitian yang dilakukan, maka dapat ditarik simpulan sebagai berikut. (1) Prestasi belajar mahasiswa yang aktif dalam organisasi kemahasiswaan Fakultas Ekonomi Universitas Pendidikan Ganesha memiliki nilai IPK rata rata 3,36. Rata-rata nilai prestasi belajar mahasiswa yang aktif dalam organisasi kemahasiswaan tergolong dalam kategori yang sangat baik. (2) Prestasi belajar mahasiswa yang tidak aktif dalam organisasi kemahasiswaan Fakultas Ekonomi Universitas Pendidikan Ganesha memiliki nilai rata-rata memiliki nilai IPK 2,80. Rata-rata nilai prestasi belajar mahasiswa yang tidak aktif dalam organisasi kemahasiswaan tergolong dalam kategori baik. (3) Ada perbedaan antara prestasi belajar mahasiswa yang aktif dan tidak aktif dalam organisasi kemahasiswaan Fakultas Ekonomi Universitas Pendidikan Ganesha. Berdasarkan hasil pengujian hipotesis penelitian diperoleh $t_{\text {hitung }}$ (equal variance assumed) 8,974 dan ttabel dengan taraf signifikan 5\% diperoleh 1,969. Ini berarti bahwa $t_{\text {hitung }}>$ $t_{\text {tabel }}(8,974>1,969)$. Hasil analisis Independent Sample T test tersebut menunjukan bahwa ada perbedaan yang meyakinkan antara prestasi belajar mahasiswa yang aktif dan tidak aktif dalam organisasi kemahasiswaan Fakultas Ekonomi Universitas Pendidikan Ganesha.

Berdasarkan simpulan hendaknya semua mahasiswa memanfaatkan organisasi untuk wahana dalam mengembangkan pengetahuan Soft skills, bakat dan minat, karena dalam organisasi akan tercipta interaksi antara mahasiswa untuk berbagi infomasi tentang perkembangan ilmu pengetahuan maupun tentang kehidupan sosial. Mahasiswa yang aktif dalam organisasi kemahasiswaan harus mampu membagi waktu antara perkuliahan dan organisasi yang diikuti demi mencapai prestasi yang memuaskan. Organisasi kemahasiswaan akan sangat berguna jika didukung dengan penyediaan fasilitas dan pengawasan oleh perguruan tinggi dalam pengembangan bakat dan minat mahasiswa baik dalam kulikuler maupun kokulikuler. 


\section{Daftar Rujukan}

Arikunto, Suharsimi. 2006. Prosedur Penelitian (Suatu Pendekatan Praktik). Jakarta: PT Rineka Cipta.

Abdul Haris Zuhad. 2008. Studi Komparasi Prestasi Belajar Mahasiswa Antara Yang Aktivis Dan Yang Nonaktivis Program S.1 Angkatan 2004 Di Iain walisongo Semarang. Tersedia.pada:http://library.walisongo.ac.id/digilib/files/disk1/78/jtptiain-gdl-abdulharis-38621-3102305_-p.pdf (diakses pada 13 Ferbruari 2013)

Bahri Djamarah, Syiful. 2008. Psikologi Belajar. Jakarta: PT. Rineka Cipta.

Bungin, Burhan. 2008. Metode Penelitian Kuantitatif. Kencana Prenada Media Group: Jakarta

Handayani, Putri. 2011. Studi Komparatif Kinerja Guru Belum Bersertifikat Pendidik Dengan Kinerja Guru Bersertifikat Pendidik Di Sekolah Menengah Kejuruan Negeri 1 Singaraja Tahun Pelajaran 2010/2011.(tidak diterbitkan).Undiksha

Undang-Undang No. 12 Tahun 2012 Pasal 77 tentang Tentang Pendidikan Tinggi, Tersedia pada : http://sipuu.setkab.go.id/PUUdoc/17624/UU0122012_Full.pdf (diaskes pada 13 Februari 2013)

Universitas Pendidikan Ganesha. 2009. Pedoman Penulisan Skripsi dan Tugas Akhir Program Sarjana dan Diploma. Singaraja : Undiksha

Universitas Pendidikan Ganesha. 2012. Pedoman Studi Universitas Pendidikan Ganesha Tahun 2012. Singaraja : Undiksha

Universitas Pendidikan Ganesha. 2012. Panduan Ekstrakulikuler Universitas Pendidikan Ganesha Singaraja Tahun 2012. Singaraja : Undiksha

Riduwan, dkk. 2011. Cara Mudah Belajar SPSS 17.0 dan Aplikasi Statistik Penelitian. Bandung: Alfabeta.

Syah, Muhibbin. 2010. Psikologi Pendidikan dengan Pendekatan Baru. Bandung: PT Remaja Rosdakarya

Suryabrata, Sumadi. 2002. Psikologi Pendidikan. Jakarta: Raja Grafindo Persada

Supriyadi, T. (2003). Kontribusi Proses Bimbingan Akademik Terhadap Prestasi Belajar Mahasiswa JurusanPendidikan Teknik Bangunan FPTK UPI. Skripsi. Pada FPTK UPI Bandung: tidak diterbitkanhttp://repository.upi.ac.id (diakses pada 31 Maret 2013)

Sutratinah Tirtonegoro. 2001. Penelitian Hasil Belajar Mengajar. Surabaya: Usaha Nasional.

Sugihartono, dkk. 2007. Psikologi Pendidikan. Yogyakarta: UNY Press

Slameto. 2010. Belajar dan Faktor-faktor yang Mempengaruhinya. PT Rineka Cipta: Jakarta.

Sugiyono. 2009. Metode Penelitian Kuantitatif Kualitatif dan R\&D. Álfabeta: Bandung.

------, 2010. Metode Penelitian Kuantitatif Kualitatif dan R\&D. Álfabeta: Bandung.

Siregar, Syofian. 2011.Statistika Deskriptif untuk penelitan. Jakarta: Raja Grafindo Persada

Sagala, Syaiful. 2008. Budaya dan Reinventing Organisasi Pendidikan. Pemberdayaan Organisasi. Pendidikan kearah yang lebih professional dan dinamis di Provinsi, Kabupaten/Kota, dan Satuan Pendidikan. Bandung: Alfabeta.

Siagan, Sondang P. 2006. Filsafat Organisasi. Bumi Aksara: Jakarta.

Wahyono, Teguh. 2009. 25 Model Analisis Statistik dengan SPSS 17. PT Elex Media Komputindo: Jakarta 